This is an electronic reprint of the original article. This reprint may differ from the original in pagination and typographic detail.

Author(s): Meriläinen, Niina; Vos, Marita

Title: $\quad$ Framing issues in the public debate: the case of human rights

Year: $\quad 2013$

Version:

Please cite the original version:

Meriläinen, N., \& Vos, M. (2013). Framing issues in the public debate: the case of human rights. Corporate Communications, an International Journal, 18(1), 119-134. https://doi.org/10.1108/13563281311294164

All material supplied via JYX is protected by copyright and other intellectual property rights, and duplication or sale of all or part of any of the repository collections is not permitted, except that material may be duplicated by you for your research use or educational purposes in electronic or print form. You must obtain permission for any other use. Electronic or print copies may not be offered, whether for sale or otherwise to anyone who is not an authorised user. 


\title{
Framing issues in the public debate: the case of human rights
}

\author{
Niina Meriläinen and Marita Vos, University of Jyväskylä, Finland
}

\begin{abstract}
Purpose - The purpose of this paper is to better understand how issues may be framed in public debate. The outcomes of this debate affect organizations. The study is based on the seven types of framing identified by Hallahan (1999) and scrutinizes which of these types is utilized, and how this is done, in the case of human rights issues.
\end{abstract}

Design/Methodology/Approach - For this study a secondary analysis of academic papers on human rights issues was conducted. After a literature search, 40 papers originating from 23 different journals were further analysed. Where the researchers described the framing of human rights issues, the type of framing was identified according to the typology and mode of utilization.

Findings - In the case of human rights all seven framing types were found; however, the most common were the framing of attributes in which the economic or cultural context was emphasized, and the framing of situations pointing out power differences between the actors.

Research limitations/implications - The study underlines the complexity of framing and the importance of awareness of framing processes. It shows that the framing typology provides valuable insights into the debate on social issues, inspiring further research.

Practical implications - This study provides a better understanding of the processes of issue framing, an important part of corporate communication strategies.

Social implications - The study adds to actor and audience awareness of framing.

Originality/value - Insights from framing theory are applied to the debate on social issues, thereby offering a fresh perspective on research in this field and relevant to corporate social responsibility.

Keywords - Framing, issues management, human rights.

Paper type - Research paper 


\section{Introduction}

The purpose of this paper is to better understand how issues may be framed in the public debate. Organizations participate in this debate because the outcomes affect them. This paper discusses current insights from framing theory to clarify the process of framing and why it is important in the public debate. Furthermore, a framing typology, based on Hallahan (1999), which can serve as a basis for analyzing the debate on issues, is described. Next, the methodology is explained and the case of human rights issues is introduced. To further analyse the framing of human rights issues in the public debate, a secondary analysis of scientific papers is conducted. Based on this analysis, conclusions are drawn on how human rights issues are framed, and how the types of framing used in the public debate can be further investigated.

The concept issue refers to how a topic is seen and discussed. According to Hallahan (2001, p. 28), "Issues are social constructions that can exist independently of the verifiable conditions on which they are based". Consequently, people can perceive the same issue differently and emphasize different aspects of an issue in expressing their views.

Social issues often concern broader problems that are relevant for various actors with different views and interests; examples include product safety and the environment (Carroll, 1979).

Solving such a problem may need action by more actors, including companies, which in turn calls for dialogue. This dialogue is in part conducted within the public debate. Human rights are a good example of a social issue, since these rights are universally accepted as a principle and yet often violated. Violations need to be investigated, and this process calls for the participation of multiple parties.

A better understanding of framing processes helps organizational decision-making on issues management and communication strategies in the public debate. In the interaction on issues, participants may be individuals and representatives of companies, governmental organizations, and/or non-governmental organizations (NGOs). Discussion on social issues is often initiated by NGOs. A previous paper in this journal focused on agenda setting by human rights organizations (Meriläinen and Vos, 2011); this paper goes beyond the drawing of attention to issues and investigates processes of framing, with a focus on how human rights issues are portrayed in the public debate. The aim is to further understanding on the framing of issues. How to frame an issue is a strategy choice that has an impact on the course of the public debate. Organizations need to be aware of the ways in which framing may be used by all the actors in the debate.

\subsection{Framing of issues}

At its core, framing refers to the placing of emphasis on particular aspects of the object of interest. According to Entman (1993, p. 52) to frame means "to select some aspects of a perceived reality and make them more salient in a communicating text, in such a way as to promote a particular problem definition, causal interpretation, moral evaluation, and/or treatment recommendation". As framing stresses certain aspects over others, it is a selective process (Lecheler and De Vreese, 2010). Framing affects how the public views items (Brewer and Gross, 
Meriläinen, N. and Vos, M. (2011), Framing issues in the public debate: the case of human rights. Corporate Communications, an international journal, Volume 16, Issue 4, pp. 293 - 310. DOI: 10.1108/13563281311294164

2005). Framing may work in two ways: indirectly, where the goal is to influence belief importance, and directly, where new considerations and connections between thoughts are aimed at (De Vreese, Boomgaarden and Semetko, 2011). Framing is an ongoing process, which has effects on the surrounding environments and publics (Benford and Snow, 2000). Framing makes some aspects of an issue more salient in the definition of situations, thus providing context. Moreover, both topic and situation affect how opinions are shared (Hayes, 2007).

Originally, the news media in particular were seen as the instigators of framing. Cohen (1963, p. 13) stated that "The press... may not be successful much of the time in telling people what to think, but it is stunningly successful in telling its readers what to think about." This refers to agenda setting in the media, which has been discussed by many authors (McCombs and Shaw, 1972; Sheafer, 2007; Larcinese, Puglisi and Snyder Jr., 2011). Framing is used in different ways, but generally coverage of issues by the media has an effect on public opinion (Dunaway, Branton and Abrajano, 2010). Journalists make choices in emphasizing issues and in the use of phrases and images, which then influence public perceptions (Nelson, Clawson and Oxley, 1997). The influence of the media, however, goes beyond agenda setting; framing occurs when the particular way in which issues are characterized in the media has an influence on how they are understood by the audience (Scheufele and Tewksbury, 2007).

While the news media have an important role in the process of framing issues, changes in communication technology and civil society have created a more complex picture. Uscinski (2009) argues that the power of the media to influence public opinion should not be overestimated, and proposes the concept of an audience-driven framework, where the public also influences the media. Many actors may be involved in the debate on various media platforms. Framing is visible in the news media, but also in the social media and in interpersonal communication.

Framing can be seen as an activity involving several actors, each influencing what aspects of an issue are regarded as salient by the other actors. The aim of framing may be to influence values and beliefs, or to influence decision-making and behaviour. Both objectives are interconnected, as once values are affected, behaviour may ensue and vice versa. Brewer and Gross (2005) describe a value frame as a connection between a value and an issue, presenting a particular aspect of an issue as being right. Values are essential motivational beliefs about outcomes or favourable modes of individual behaviour (Kilburn, 2009). Therefore, actors operate as moral entrepreneurs, and influence opinions through value-setting.

The public is not a homogeneous entity; rather, people have different values and experiences, and therefore different frames can be important to different people. Issues become salient to people when they are familiar with them and have experience of them (Thøgersen, 2006). The salience of an issue can be enhanced through exposing people frequently to familiar frames (Nelson, Oxley and Clawson, 1997; Chong and Druckman, 2007). Consequently, when an issue is salient to people, they are likely to do a considerable amount of processing of that issue because they are both motivated and able, due to their cognitive abilities, to do so (Petty, Cacioppo and Goldman, 1981). Thus, actors can frame an issue as salient either through value framing or familiarity framing. 
Meriläinen, N. and Vos, M. (2011), Framing issues in the public debate: the case of human rights. Corporate Communications, an international journal, Volume 16, Issue 4, pp. 293 - 310.

DOI: 10.1108/13563281311294164

An issue does not exist in isolation of other issues, and may remain relevant for about four to six weeks (Winter and Eyal, 1981). The effects of different frames vary (De Vreese, Boomgaarden and Semetko, 2011). According to Hilgartner and Bosk (1988) it is frames that compete with each other for the attention of publics. According to Zhu (1992), framing is directed by the zero-sum game rule, like agenda setting in which the raising of one issue leads to the demise of another. The selective interests of people influence how many issues can be salient at any one time. Using the right kind of frame can help achieve salience for more than just one issue at a time. To select which issues to focus on for framing calls for issues management.

\subsection{Issues management}

Issues management was introduced as a field of public relations in the business environment in the mid-seventies (Heath and Nelson, 1988 and 2002). From the perspective of an individual organization it encourages anticipation of the interests of public groups by monitoring the public debate on issues related to its core functions, and deciding where and when to participate in that debate. According to Heath (1998, p. 274), “Issues management is a function dedicated to helping organizations to understand and strategically adapt to their public policy environment.” It contributes to social coherence by creating a dialogue "between the organizational culture and that of publics and stakeholders within the larger society” (Bowen and Heath, 2005, p. 85). Organizations cannot afford to distance themselves from their social environment, but need to have a reflective and inclusive approach (Waymer and Heath, 2007). During issues management analysis, the salience of issues related to the organization and its stakeholders as well as suitable communication tools are evaluated (Vos and Schoemaker, 2006). Issues managers are responsible for analyzing issues and making strategic decisions about which issues are relevant (Bowen, 2004).

According to Coombs (1992), involvement in public policies is the original and the biggest objective of issues management - it is a proactive task of addressing internal and external issues. In the long term this type of participation can also enhance an organization's value creation and thus help it to outperform competitors (Hillman and Keim, 2001). From the perspective of the individual organization, issues management can be seen as a tool; however, it needs a dialogue in which publics and other organizations are taken into account. Issues may be related to company crises. Coombs (2007) pointed out the relevance of emotions in such cases. Emotions are also important when issues are discussed in the social media. Coombs suggests the notion of issue contagion to describe the fast development of issues in the internet environment (Coombs, 2002).

In debate on social issues, larger numbers of actors, each with their own point of view, are involved, and the debate takes place on various platforms on the local, national or international level. These real or virtual platforms are known as issue arenas, where the attention devoted to issues changes over time, the actors may become more or less active and new actors may emerge (Luoma-aho and Vos, 2010). To participate effectively in issue arenas, an actor has to be familiar with the other actors and relate to their points of view on the issues concerned. For this purpose issues management, providing not only an overview of the issues and actors involved, but insight into the content of the issue and issue framing, is also needed. 


\subsection{Credibility, legitimacy and power}

In the public debate, several actors can try to influence people's opinions. To become a central player in the issue arena, an actor needs perceived credibility, legitimacy and power. These characteristics are all connected to one another. Credibility, legitimacy and power influence not only framing, but also the ownership of issues. The reputation of an actor influences whether that actor can claim ownership to an issue (Meijer and Kleinnijenhuis, 2006). Actors can thus achieve prominence in their stand on issues if they have high credibility, legitimacy and power.

According to Druckman (2001), a precondition for successful framing is perceived source credibility. Actors can use their source credibility also to create issue credibility. People choose which frames to follow depending on the actors who present the frames. Coombs (1992) emphasizes legitimacy and suggests as a first step establishing issue legitimacy to attract publics to the issue, as a second step the organization's own legitimacy to get the audience to listen to its ideas, and as a third step policy proposal legitimacy to support the policy proposals for resolving issues.

Not all actors are equally able to define issues as salient by demonstrating power in functioning as gatekeepers. Only the bigger and central actors, called hubs, can influence issue salience, while smaller actors may need to collaborate with them to do so (Carpenter, 2010 and 2011). If more actors compete in the same arena, the actor whose frame is accepted and who is more credible, legitimate and powerful, will own the issue in the debate. As Petrocik (1996, p. 847) observes, to gain issue ownership, "issue handling competence is the key".

If an actor has ownership of an issue, this may enable power. Bachrach and Baratz (1962) mention two kinds of power, decision-making and non-decision making. In decision-making the actor participates to make other actors decide something, whereas in non-decision-making, issues are intentionally kept out of the discussion, which may render them less visible (Anton, 2007: 25). Lukes (1974) added a third kind of power, the ability to influence public values and points of view.

Different actors appear more credible, legitimate and powerful to different groups of people. For example, an organization may be seen as an authority in a familiar issue arena while in a new issue arena it needs to make an effort to enjoy the same kind of legitimacy. Without legitimacy, issue managers are left without a voice or the attention of publics (Coombs, 1992). The interaction between the actors in the issue arena may change public perceptions of their credibility, legitimacy and power. Once actors have successfully framed an issue, they have established their position and acquired better possibilities to engender discussion and influence opinions on a later occasion.

\subsection{Types of framing}

As discussed above, issues are considered to be a social construct, and issues represent broad complex topics involving various actors with different points of view. In their communication about an issue, different actors emphasize different aspects of that issue. Which aspects are emphasized depends on the strategy chosen. The effectiveness of a framing strategy will be influenced by the perceived credibility, legitimacy and power of the actors. 
Meriläinen, N. and Vos, M. (2011), Framing issues in the public debate: the case of human rights. Corporate Communications, an international journal, Volume 16, Issue 4, pp. 293 - 310.

Framing strategies can be very diverse, but can nevertheless be categorized according to a framing typology. Each framing type emphasizes different aspects of the issue. Hallahan (1999) introduced seven types of framing: (1) framing of situations, (2) attributes, (3) choices, (4) actions, (5) issues, (6) responsibilities and (7) news. For social issues all seven types of framing may be relevant. For example, framing of the situation entails setting the scene by stressing how the actors are interrelated and, for example, making it clear who is the underdog in the situation. In this study this typology is applied to social issues.

The way in which an issue is framed shows how it is seen. When discussing an issue, different descriptions and arguments are used that emphasize different aspects of the issue. People are invited to see the situation in a particular light, which may affect their views on the issue. The choice of framing strategy will depend on the issue and the interests of the actor. The interplay of the actors in the debate may exhibit different types of framing.

\section{Method}

This paper aims to contribute to understanding of how issues may be framed in the public debate, by investigating which types of framing are used and how this is done. The authors do not take a normative point of view, accepting or rejecting particular types of framing; on the contrary we assume that communication and sense making is not possible without emphasizing some elements and leaving out others, i.e., without framing a topic one way or another. Making actors and audiences more aware of framing may clarify the dialogue on issues.

As there are numerous social issues, the focus here is on one area, human rights. Human rights issues have been discussed broadly and included in UN treaties. The Declaration of Human Rights was drafted after the Second World War in 1948, but human rights continue to be violated throughout the world. Human rights issues are recognized as social issues and debated by multiple actors.

The research questions are the following: Which types of framing are used in the debate on human rights issues (RQ1)? How is framing used to increase the salience of human rights issues (RQ2)?

The material for the analysis was collected from scientific papers, as many exist on the topic of human rights and how they are discussed. The scientific literature on human rights was chosen as the data source as it summarizes multiple views on these issues. It also describes issues in detail, along with examples of multiple cases, while giving a broad overview, including views of e.g. NGOs, states and corporations. A thematic analysis of refereed academic papers was conducted to clarify the framing of human rights issues in the literature.

\subsection{Operationalizing the types of framing}

The types of framing were based on the typology by Hallahan (1999), who identified seven types of framing (see section 1.4). To operationalize the types of framing in the case of social issues, the researchers studied the description of the types given by Hallahan (1999) in order to adhere as closely as possible to his typology. The labels and descriptions of the types were adapted to facilitate their application to social issues. To distinguish 'framing of attributes' from the other 
types, we added context, as this may be done by linking the issue to a context or to other topics. Thus, this form of framing emphasizes the link with related topics and how issues are connected with one another. For 'framing of choices' the description referred to how risky the choices were portrayed as being, and so we rephrased this type as 'focus on risky choices', as many social issues are related to risks and in the interaction a high level of risk may be suggested to influence perceptions. In the description of 'framing of issues', Hallahan emphasizes the kind of issue in question, hence we rephrased this as 'focus on the kind of issue', as in our case the whole list of framing types was to be applied to social issues. These small adaptations remained faithful to Hallahan. As we earlier defined framing as rendering some aspects more salient in a communicating text (Entman, 1993) and acknowledged that this emphasizes certain elements over others, we refer to this process as adding a focus on certain aspects.

Based closely on the typology of Hallahan (1999) we list the following types of framing of social issues:

1. Focus on situations allows examination of the interrelatedness of actors, their interests and relations, e.g. paying attention to who is top dog and who is an underdog.

2. Focus on context attributes focuses on characteristics that are emphasized or ignored, linking the issue to a context or other topics.

3. Focus on risky choices means evaluating situations where uncertainty is present, stressing the uncertainties and risks involved.

4. Focus on actions refers to evaluating the beneficial or problematic consequences of issues, making action appear necessary in achieving desired goals or avoiding negative consequences.

5. Focus on the kind of issue involves alternative ways of looking at the issue as a relevant social or economic problem, by emphasizing e.g. political, legal, historical, cultural or economic aspects of the issue.

6. Focus on responsibilities examines the responsibilities of actors and their role in the events of interest, e.g. attributing cause and blame.

7. Focus on news means emphasizing the news as a source and newsworthy elements of events.

\subsection{Thematic analysis}

The literature was found by a metasearch via the EBSCO host and adding papers by the snowball technique. For the literature search several keywords were used: human rights, human rights NGOs, framing and issue attention. No year boundaries were used in the literature search, which was concluded in September 2011.

The literature search provided 50 papers that were first checked to see if they indeed fitted the keywords. After this check, 40 papers were chosen for the analysis. They came from 23 different journals. The biggest number of articles came from the Human Rights Quarterly with 11 papers. The second highest number came from the Journal of Conflict Resolution with 3 articles. The journals with two articles were International Organizations, The American Journal 
Meriläinen, N. and Vos, M. (2011), Framing issues in the public debate: the case of human rights. Corporate Communications, an international journal, Volume 16, Issue 4, pp. 293 - 310.

of International Law, Human Rights Review, International Studies Quarterly, and Corporate Communications: An International Journal. The remaining journals provided one paper each.

Each of the 40 papers was read and analysed. Where the authors described the framing of human rights issues, the text fragments were copied into the database. Per paper, these totalled 29 fragments. A total of 500 fragments were entered into the database that consisted of a table containing 80 pages.

The seven types of framing served as a coding scheme. The size of a piece of coded text varied from a sentence to a multi-sentence chunk. They were coded by assigning the single most appropriate code in the list. This was done by one researcher while the second researcher, to increase reliability, checked the coding. After discussing about $20 \%$ of the codes to reach consensus, the coding was finalized.

In the next step the number of text fragments was added up, and a table and pie chart were made. Then the researchers went back to the database to reread the fragments, but now by framing type to summarize how each type of framing was utilized.

\subsection{The case of human rights issues}

The Universal Declaration of Human Rights consists of 30 articles and includes, for example, the following: "No one shall be held in slavery or servitude; slavery and the slave trade shall be prohibited in all their forms. No one shall be subjected to torture or to cruel, inhuman or degrading treatment or punishment.” (UN, 1948: article 4 and 5).

Human rights have been universally accepted as a principle and affect everyone. States and corporations, however, may permit human rights violations to occur since such violations are profitable and are deemed to be justified to achieve a certain political goal (Engle, 2004; Muchlinski, 2001). Multinational corporations and private security forces have been accused of violating human rights (e.g. Weiss and Shamir, 2011), while sanctions have also been used to pressure states to better their human rights (Goldstone, 2011). Another example is the trafficking and exploitation of women, a large scale criminal business (Hughes, 2000), which is allowed to continue through the practices of western organizations (Bell and Keenan, 2004; Mendelson, 2005). From the perspective of corporate social responsibility companies address human rights issues.

In the public debate attention to human rights issues is often initiated by human rights organizations that investigate and report human rights violations, for examples Amnesty International and Human Rights Watch. Human rights organizations have been successful in putting human rights issues on the public, media and political agendas (Dhir, 2007; Soh, 1996) and they have had an impact on human rights performance (Murdie, 2009). Human rights and how they are discussed have been studied in the academic literature, but this paper adds to the existing body of knowledge by its focus on the framing of human rights issues. 


\section{Findings}

The research questions for the study were: Which types of framing are used in the debate on human rights issues (RQ1)? How is framing used to increase the salience of human rights issues (RQ2)? We will first look at RQ1 and then at the results regarding RQ2.

\subsection{Types of framing found}

To answer the first research question, all seven framing types described in the previous section were identified in the human rights literature. According to the thematic analysis, altogether 500 framing examples were found in the 40 scientific articles. The large number of fragments found in the articles showed that the more general types of framing also occur in human right issues. Most of the articles, 73\%, had 10 to 29 fragments, while two articles had only one fragment. The differences can be explained because the papers selected focused to a greater or lesser extent specifically on human rights.

All seven types of framing were mentioned, indicating that different aspects of human rights issues are emphasized, although in very different numbers. Figure 1 shows a pie chart with the results of the thematic analysis per framing type, while table 1 shows the numbers and percentages of the framing types found.

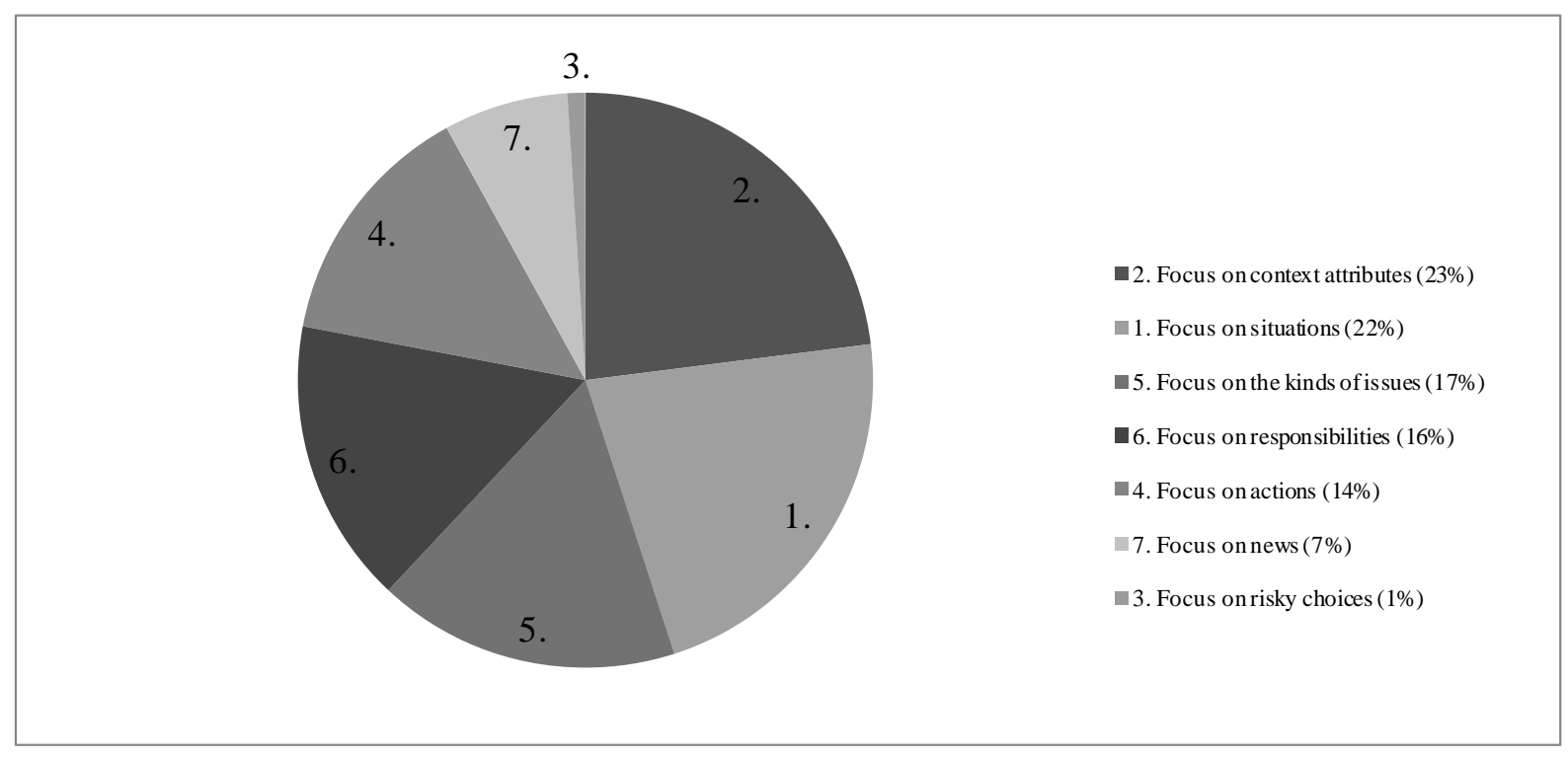

Figure 1 Pie chart of the framing types found (listed from biggest to smallest numbers).

The most commonly used types were focus on context attributes and situations, each constituting almost a quarter of the fragments. Types less often used were focus on the kind of issue, responsibilities and actions. The least used types were focus on news and risky choices. 
Meriläinen, N. and Vos, M. (2011), Framing issues in the public debate: the case of human rights. Corporate Communications, an international journal, Volume 16, Issue 4, pp. 293 - 310.

DOI: 10.1108/13563281311294164

Table 1 Overview showing how often each type of framing was used.

\begin{tabular}{|l|c|c|}
\hline Framing type & $\begin{array}{l}\text { Number of } \\
\text { times used }\end{array}$ & $\begin{array}{l}\text { Percentage } \\
\text { used }\end{array}$ \\
\hline 1. Focus on situations & $\mathbf{1 1 2}$ & $\mathbf{2 2 \%}$ \\
\hline 2. Focus on context attributes & $\mathbf{1 1 6}$ & $\mathbf{2 3 \%}$ \\
\hline 3. Focus on risky choices & 4 & $1 \%$ \\
\hline 4. Focus on actions & 69 & $14 \%$ \\
\hline 5. Focus on the kind of issue & 87 & $17 \%$ \\
\hline 6. Focus on responsibilities & 79 & $16 \%$ \\
\hline 7. Focus on news & 33 & $7 \%$ \\
\hline Sum & 500 & $100 \%$ \\
\hline
\end{tabular}

The context of human rights issues and the actors involved are frequently addressed in the literature, while other aspects, such as news or risks, are less often discussed. In the framing types used no clear change was observed over the years; the dispersion pattern seems to depend more on the area (in this case human rights issues) than on the year. The cases discussed in the sample of the human rights literature varied greatly. Most discussed were e.g. oil companies, workers' rights, human trafficking, rape, women's rights, genocide and the significance of human rights treaties.

\subsection{How is framing used?}

To investigate RQ2, that is, in what ways framing is used to increase the salience of human rights issues, a closer look was taken at each framing type and how it was used in the literature.

\section{Focus on situations}

This framing type examines the interrelatedness of actors, their interests and relations, e.g. paying attention to who is top dog and who is an underdog. In the literature there were many fragments in which the power of the different actors involved was discussed, thereby providing an explanation of the factors leading to the continuance of human rights violations. In some cases this suggested directions for finding rational solutions, or in other cases, in a more emotional appeal, portrayed the situation as a battle between David and Goliath. Examples are given below.

"A further consequence is that the international human rights regimes are comparatively weak compared to, say, the regimes of finance or trade" (Neumayer, 200, p. 926). 
Meriläinen, N. and Vos, M. (2011), Framing issues in the public debate: the case of human rights. Corporate Communications, an international journal, Volume 16, Issue 4, pp. 293 - 310.

DOI: 10.1108/13563281311294164

Clearly reconciliation cannot occur where power relationships remain unchanged, where "truth" continues to be defined by the dominant group, and where the marginalized groups remain outside the negotiation of discourse" (Mazzei, 2011, p. 439).

\section{Focus on context attributes}

This type of framing examines characteristics that are emphasized or ignored by linking the issue to a context or other topics. In the literature the cultural context of human rights violations was addressed. Furthermore, there were many fragments in which the human rights perspective of an issue was emphasized in order to draw attention to a desired change. For example, environmental issues were linked to human rights issues to gain more attention. Similarly, climate change was related to human rights and inequality ('apartheid').

"First, the testimonies of women made it apparent that violence against women may differ across regions and countries but that it is a universal phenomenon. Second, in their testimonies, women assigned blame to patriarchal structures and traditions for the existence of the problem. Lastly, the testimonies were dramatic” (Joachim, 2003, p. 255).

"This linkage between human rights and environmental protection is gaining greater traction now in a variety of ways. A growing cross-section of civil society actors, high-level state representatives, and academics, for one thing, is arguing that the roots of climate change lie not solely in market failures, for example, or the inadequate deployment of green technologies, but rather in exploitative relations of power" (Nicholson and Chong, 2011, p. 122).

“Climate apartheid” (Nicholson and Chong, 2011, p. 128).

\section{Focus on risky choices}

This type of framing entails evaluating situations where uncertainty is present, stressing the uncertainties and risks involved. In some of the literature fragments, human rights issues were presented in such a manner that emphasis was placed on risks created by doing or not doing something, highlighting threats or danger.

"First and foremost, all those actors concerned with human rights protection, internal and external, should recognize that a peace process contains both opportunities and threats for the protection of human rights. It should be recognized that many of these opportunities and threats cannot be appropriately planned for, and that difficulties and mistakes are inevitable" (Bell and Keenan, 2004, p. 372-373).

"Returning to Burma is often not an option, due to fighting, fear of military patrols, and fear of rape. Returning to Thailand often means returning to the sex trade” (Beyrer, 2001, p. 546). 


\section{Focus on actions}

This framing type evaluates the beneficial or problematic consequences of issues, making action appear necessary in achieving desired goals or avoiding negative consequences. In the literature the importance of human rights organizations in creating solutions in the case of human rights violations was stressed. Next to positive aspects, negative aspects were also addressed, emphasizing what may happen if human rights organizations or other actors are unable to initiate global solutions.

"It is because of the complicated and highly political nature of the relationship between globalization and human rights that the anti-globalization social movement has emerged" (Howard-Hassmann, 2005, p. 16).

"NGOs including HRW and AI condemned the Israeli operation and presented a chronology that downplayed or erased the context of Hamas attacks that preceded the Israeli incursion" (Steinberg, 2011, p. 38).

\section{Focus on the kind of issue}

This type of framing involves alternative ways of looking at an issue as a relevant social or economic problem. By emphasizing e.g. political, legal, historical, cultural or economic aspects of an issue, actors are able to view the issue from alternative perspectives. In the literature fragments, this type of framing was used to portray issues as human rights issues that previously were not seen as such. In the case of economic or legal matters the human rights aspects were emphasized.

"Far from enjoying the fruits of prosperity, women in the Niger Delta have been adversely impacted by oil exploration. Ethnic violence fueled by competition over oil money has destroyed lives in many villages across Southeast Nigeria" (Dhir, 2007, p. 80).

In sum, international law has an important role to play in constructing a better functioning global regime to govern business and human rights. The effectiveness of its contributions will be maximized if it is embedded within, and deployed in support of, an overall strategy of increasing governance capacity in the face of enormously complex and ever-changing forces of globalization” (Ruggie, 2007, p. 840).

\section{Focus on responsibility}

This framing type examines the responsibilities of actors and their role in the events in question, e.g. attributing cause and blame. In the literature, the responsibilities of various actors were discussed, with an emphasis on what could be expected from companies and states in supporting human rights, as well as pointing out actors that had contributed to human rights violations. 
Meriläinen, N. and Vos, M. (2011), Framing issues in the public debate: the case of human rights. Corporate Communications, an international journal, Volume 16, Issue 4, pp. 293 - 310.

DOI: 10.1108/13563281311294164

"First, MNEs (Multinational enterprises) are in business. Their only social responsibility is to make profits for their shareholders. Second, private non-state actors, such as MNEs, do not have any positive duty to observe human rights. Their only duty is to obey the law. Thus it is for the state to regulate on matters of social importance and for MNEs to observe the law. Third, which human rights are MNEs to observe? They may have some influence over social and economic matters...but they can do nothing to protect civil and political rights" (Muchlinski, 2001, p. 35).

"New human rights abuses may enter the field with the entry of peace-keepers and the international community itself. Problems of accountability of international personnel involved in governance more generally have emerged in Bosnia, and to a greater extent in the United Nations administrations in Kosovo and East Timor. Problems of trafficking against women, sexual slavery and rape have all been well documented as issues that accompany armies, including peace-keepers” (Bell and Keenan, 2004, p. 342).

\section{Focus on news}

This type of framing means emphasizing the news as a source and newsworthy elements of an issue. The literature addressed how news stories are used as a source of information on human rights issues, and how the media agenda may affect the public agenda in drawing attention to human rights. In many fragments the importance of discussing human rights issues in the news media was emphasized. This concerns not only whether human rights violations are reported in the media but also the way in which they are portrayed.

"For better or worse, media coverage of this propagandized "review" of the Holocaust was extensive. Implicit in the coverage, it seemed, was the impression that what was happening in Tehran was somehow typical of a broader trend of Holocaust denial throughout the world, and particularly in the Third, or developing, World... A closer examination of the Tehran conference reveals, however, that most presenters constituted a well-known, if not notorious, group of First World Holocaust deniers" (Miles, 2009, p. 506).

"The literature on media framing of public policy suggests that the media coverage of human trafficking has been framed in a way that has marginalized alternative views on trafficking and criticisms of current policy and, as a result, legitimized the dominant view on trafficking and approach to combating trafficking” (Gulati, 2011, p. 367).

\subsection{Framing of human rights issues}

All seven types of framing were found among the literature fragments on human rights and the analysis clarified in which way each type was used. Table 2 presents a summary of the results. 
Meriläinen, N. and Vos, M. (2011), Framing issues in the public debate: the case of human rights. Corporate Communications, an international journal, Volume 16, Issue 4, pp. 293 - 310.

DOI: 10.1108/13563281311294164

Table 2 Summary of types of framing found and their use in the case of human rights issues.

\begin{tabular}{|l|l|l|}
\hline Type of framing & Percentage & Application to human rights issues \\
\hline $\begin{array}{l}\text { Focus on context } \\
\text { attributes }\end{array}$ & $23 \%$ & $\begin{array}{l}\text { Linking issues to a human rights frame, by emphasizing } \\
\text { human rights aspects and adding a human rights point of } \\
\text { view to the issue. }\end{array}$ \\
\hline Focus on situations & $22 \%$ & $\begin{array}{l}\text { Addressing the power of various actors and inter-relations } \\
\text { of human rights NGOs and other actors. }\end{array}$ \\
\hline $\begin{array}{l}\text { Focus on the kind of } \\
\text { issue }\end{array}$ & $17 \%$ & $\begin{array}{l}\text { Relating human rights to other issues and placing human } \\
\text { rights in an economic or cultural context. }\end{array}$ \\
\hline Focus on responsibility & $16 \%$ & $\begin{array}{l}\text { Addressing the responsible actors in human rights } \\
\text { violations and stressing their responsibility in the issue. }\end{array}$ \\
\hline Focus on news & $7 \%$ & $\begin{array}{l}\text { How human rights issues are portrayed in the news and } \\
\text { how news stories are used as a source of information on } \\
\text { human rights issues. }\end{array}$ \\
\hline Focus on risky choices & $1 \%$ & $\begin{array}{l}\text { Emphasizing threats related to human rights issues and } \\
\text { risks of acting or not acting on human rights violations. }\end{array}$ \\
\hline
\end{tabular}

\section{Conclusions and discussion}

The purpose of this paper was to better understand how issues are framed in the public debate. The study was based on the seven types of framing identified by Hallahan (1999) and scrutinized which of these types were utilized, and how this was done, in the case of human rights issues. The data were derived from an analysis of a sample of the academic literature on human rights. This offered a broad overview of cases, yielding different viewpoints. Thematic analysis provided an understanding of how human rights issues are framed.

The research questions were, which types of framing are used in the debate on human rights issues (RQ1), and how is framing used to increase the salience of human rights issues (RQ2)? To answer these questions, a thematic analysis of 40 reviewed articles was conducted in which the seven types of framing served as a coding scheme.

First, to answer RQ1, all seven framing types were identified in the human rights material. Altogether 500 frame fragments were found in the 40 articles. The most commonly used framing types were the focus on context attributes in which the economic or cultural context was emphasized, and focus on situations pointing out power differences between the actors.

Second, to answer RQ2, the use of each framing type was summarized. Examples provided in the literature in respect of human rights issues indicate that human rights issues are framed in different ways and emphasis is given according to the specific issue, environment and audience. The interconnectedness of issues was noted; for example climate change was linked to human rights. Furthermore, when portraying an issue, power differences between the actors, e.g. between human rights organizations and corporations, were emphasized. If the goal is to gain salience for human rights over a long period of time, it seems probable that not all issues can be 
Meriläinen, N. and Vos, M. (2011), Framing issues in the public debate: the case of human rights. Corporate Communications, an international journal, Volume 16, Issue 4, pp. 293 - 310.

framed in the same manner, and with time particular issues may need new frames to render them salient again. Using frames that resonate with public perceptions may help in achieving issue salience. Since human rights issues are sensitive, the frame needs to be chosen carefully. It should be noted that not all instances of framing will be intentional and framing cannot be avoided, as all storylines are the outcome of a process of selection.

This study, by underlining the complexity of framing, has implications for practice. It shows that the actors in the debate need to be aware of framing processes. In issues management the details of framing processes need to be taken into account. Framing emphasizes particular aspects of an issue. Different actors will frame an issue differently in accordance with their interests. Not everyone has an equal say in the public debate, as the factors of credibility, legitimacy and power differ. The actors may set their own objectives and seek to raise the level of specific factors. Actors may also aim at keeping issues out of the discussion. Effective framing requires decision-making, while also taking the behaviour of other actors in the debate into account. Framing draws attention to different aspects of an issue in a selective manner, emphasizing some and downplaying others. Therefore, framing, like agenda setting, can be considered a zero-sum game. Insight into the complexity of framing processes adds to awareness by actors and in this way contributes to decision-making on the organizational communication strategies to be deployed in the issue arena.

The study also has implications for research. It showed that investigating framing on the basis of Hallahan's (1999) typology provides a profound insight into the debate on issues, in this case human rights issues, revealing what is underlined in the debate by the various actors and revealing the interrelatedness of issues and the power structures that subsist between different actors.

Naturally, this study also has its limitations. It focused on a broad range of human rights issues, as discussed in the academic literature, providing a broad overview and examples illustrating all types of framing. However, the examples also showed that how each framing type was used depends on the issue and the actors involved. Therefore, we propose to investigate other issues by using this typology to scrutinize discourse in various case studies.

By investigating a particular issue in greater depth, the complexity of framing may be addressed further. In the public debate, a combination of frames may be used, as social issues are complex and involve many actors who aim at increasing their credibility, legitimacy and power. Organizations need to understand the behaviour of their stakeholders in the relevant issue arenas. Awareness of the types of framing used helps recognize the strategies of other actors in the debate. This facilitates decision-making on organizational communication strategies including which elements to emphasize in the public debate. This study contributes to this end by clarifying types of framing. 


\section{References}

Anton, A. (2007), "Socialist Voices”, in Anton, A. and Schmitt, R. (Eds.), Toward a New Socialism, Lexington Books, Plymouth, pp. 21-52.

Bachrach, P. and Baratz, M.S. (1962), “Two Faces of Power”, The American Political Science Review, Vol. 56 No. 4, pp. 947-952.

Bell, C. and Keenan, J. (2004), "Human Rights Nongovernmental Organizations and the Problem of Transition”, Human Rights Quarterly, Vol. 26 No. 2, pp. 330-374.

Benford, R.D. and Snow, D.A. (2000), "Framing Processes and Social Movements: An Overview and Assessment”, Annual Review Sociology, Vol. 26 No.1, pp. 611-639.

Beyrer, C. (2001), "Shan women and girls and the sex industry in Southeast Asia; political causes and human rights implications”, Social Science \& Medicine, Vol. 53 No. 4, pp. 543-550.

Bowen, S.A. (2004), "Expansion of Ethics as the Tenth Generic Principle of Public Relations Excellence: A Kantian Theory and Model for Managing Ethical Issues”, Journal of Public Relations Research, Vol. 16 No. 1, pp. 65-92.

Bowen. S. and Heath, R.L. (2005), "Issues management, systems, and rhetoric: exploring the distinction between ethical and legal guidelines at Enron", Journal of Public Affairs, Vol. 5 No. 2, pp. 84-98.

Brewer, P. and Gross, K. (2005), “Values, Framing and Citizens' Thoughts about Policy Issues: Effects on Content and Quantity”, Political Psychology, Vol. 26 No. 6, pp. 929-948.

Carpenter, R.C. (2011), "Vetting the Advocacy Agenda: Network Centrality and the Paradox of Weapons Norms”, International Organization, Vol. 65 No.1, pp. 69-102.

Carpenter, R.C. (2010), “Governing the global agenda: "gatekeepers” and “issue adoption” in transnational advocacy networks”, in Avant, D. D., Finnemore, M. and Sell S.K. (Eds.), Who Governs the Globe, Cambridge University Press, Cambridge, pp. 202-237.

Carroll, A.B. (1979), “A Three-Dimensional Conceptual Model of Corporate Performance”, The Academy of Management Review, Vol. 4 No. 4, pp. 497-505.

Chong, D. and Druckman, J.N. (2007), “A Theory of Framing and Opinion Formation in Competitive Elite Environments”, Journal of Communication, Vol. 57 No. 1, pp. 99-118.

Cohen, B. C. (1963), The press and foreign policy, Princeton University Press, Princeton, NJ.

Coombs, W.T. (1992), “The Failure of the Task Force on Food Assistance: a Case Study on the Role of Legitimacy in Issues Management”, Journal of Public Relations Research, Vol. 4 No. 2, pp. 101-122.

Coombs, T. (2002), “Assessing online issue threats: issue contagions and their effect on issue prioritization”, Journal of Public Affairs, Vol. 2 No. 4, 215-229.

Coombs, W.T. and Holladay, S.J. (2007), “The negative communication Dynamic: Exploring the impact of stakeholder affect on behavioral intentions”, Journal of Communication Management, Vol. 11 No. 4, pp. 300-312.

De Vreese, C., Boomgaarden, H.G. and Semetko, H. A. (2011), “(In)direct Framing Effects: The Effects of News Media Framing on Public Support for Turkish Membership in the European Union”, Communication Research, Vol. 32 No. 2, pp. 179-205. 
Meriläinen, N. and Vos, M. (2011), Framing issues in the public debate: the case of human rights.

Corporate Communications, an international journal, Volume 16, Issue 4, pp. 293 - 310.

DOI: 10.1108/13563281311294164

Dhir, K.S. (2007), “Stakeholder activism through nonviolence”, Corporate Communications: An International Journal, Vol. 12 No. 1, pp. 75-93.

Druckman, J. N. (2001), “On the Limits of Framing Effects: Who Can Frame?” The Journal of Politics, Vol. 63 No. 4, pp. 1041-1066.

Dunaway, J., Branton, R.P. and Abrajano, M. A. (2010), “Agenda Setting, Public Opinion, and the Issue of Immigration Reform” Social Science Quarterly, Vol. 91 No.2, pp. 359-378.

Engle, E. (2004), “Corporate social responsibility (CSR): market-based remedies for international human rights violations?” Willamette law review, Vol. 40 No. 103, pp. 103121.

Entman, R.M. (1993), “Framing: Toward Clarification of a Fractured Paradigm”, Journal of Communication”, Vol. 43 No. 4, pp. 51-58.

Goldstone, R.J. (2011), “The Role of Economic Sanctions in Deterring Serious Human Rights Violations: South Africa, Iraq and Darfur”, in Provost, R. and Akhavan, P. (Eds.), Ius Gentium: Comparative Perspectives on Law and Justice 7: Confronting Genocide, Springer, Dordrecht, pp. 159-172.

Gulati, G.J. (2011), “News Frames and Story Triggers in the Media Coverage of Human Trafficking”, Human Rights Review, Vol. 12 No. 3, pp. 363-379.

Hallahan, K. (2001), “The Dynamics of Issues Activation and Response: An Issues Processes Model” Journal of Public Relations Research, Vol. 13 No. 1, pp. 27-59.

Hallahan, K. (1999), “Seven Models of Framing: Implications for Public Relations”, Journal of Public Relations Research, Vol. 11 No. 3, pp. 205-242.

Hayes, A. (2007), "Exploring the Forms if Self-Censorship: On the Spiral of Silence and the Use of Opinion Expression Avoidance Strategies”, Journal of Communication, Vol. 57 No. 4, pp. 785-802.

Heath, R. L. (1998), “New Communication Technologies: An Issues Management Point View”, Public Relations Review, Vol. 24 No. 3, pp. 273-288.

Heath, R.L. (2002), ”Issues management: Its past, present and future”, Journal of Public Affairs, Vol. 2 No. 4, pp. 209-214.

Heath, R. L. and Nelson, R.A. (1988), Issues management: Corporate public policymaking in an information society, Sage, London.

Hilgartner, S. and Bosk, C.L. (1988), “The Rise and Fall of Social Problems: A Public Arenas Model” American Journal of Sociology, Vol. 94 No. 1, pp. 53-78.

Hillman, A.J. and Keim, G. A. (2001), "Shareholder Value, Stakeholder Management, and Social Issues: What's the Bottom Line?”, Strategic Management Journal, Vol. 22 No. 2, pp. 125-139.

Howard-Hassmann, R. E. (2005), “The Second Great Transformation: Human Rights Leapfrogging in the Era of Globalization”, Human Rights Quarterly, Vol. 27 No. 1, pp. $1-40$.

Hughes, D.M. (2000), “The "Natasha” Trade: The Transnational Shadow Market of Trafficking in Women”, Journal of International Affairs, Vol. 53 No. 2, pp. 625-651. 
Meriläinen, N. and Vos, M. (2011), Framing issues in the public debate: the case of human rights.

Corporate Communications, an international journal, Volume 16, Issue 4, pp. 293 - 310.

DOI: 10.1108/13563281311294164

Joachim, J. (2003) “Framing Issues and Seizing Opportunities: The UN, NGOs, and Women's Rights” International Studies Quarterly, Vol. 47 No. 2, pp. 247-274.

Kilburn, H.W. (2009), “Personal Values and Public Opinion”, Social Science Quarterly, Vol. 90 No. 4, pp. 868-885.

Larcinese, V., Puglisi, R. and Snyder Jr. J.M. (2011), "Partisan bias in economic news: Evidence on the agenda-setting behavior of U.S. newspapers”, Journal of Public Economics, Vol. 95 No. 9-10, pp. 1178-1189.

Lecheler, S. and De Vreese, C.H. (2010), "Framing Serbia: the effects of news framing on public support for EU enlargement” European Political Science Review, Vol. 2 No. 1, pp. 73-93.

Lukes, S. (1974), Power: a Radical view, Macmillan, London.

Luoma-aho, V. and Vos, M. (2010), “Towards a more dynamic stakeholder model: acknowledging multiple issue arenas”, Corporate Communications: An International Journal, Vol. 15 No. 3, pp. 315-331.

Mazzei, J. M. (2011), “Finding Shame in Truth: The Importance of Public Engagement in Truth Commissions”, Human Rights Quarterly, Vol. 33 No. 2, pp. 431-452.

McCombs M. and Shaw, D. (1972), “The Agenda-setting Function of Mass media”, Public Opinion Quarterly, Vol. 36 No. 2, pp. 176-187.

Meijer, M.M. and Kleinnijenhuis, J. (2006), “Issue News and Corporate Reputation: Applying the Theories of Agenda Setting and Issue Ownership in the Field of Business Communication”, Journal of Communication, Vol. 56 No. 3, pp. 543-559.

Mendelson, S.E. (2005), Barracks and brothels: peacekeepers and human trafficking in the Balkans, The CSIS Press, Washington D.C.

Meriläinen, N. and Vos, M. (2011), "Human rights organizations and online agenda setting”, Corporate Communications, an international journal, Vol. 16 No. 4, pp. 293-310.

Miles, W. (2009), "Indigenization of the Holocaust and the Tehran Holocaust Conference: Iranian Aberration or Third World Trend?”, Human Rights Review, Vol. 10 No. 4, pp. 505-519.

Muchlinski, P.T. (2001), "Human rights and multinationals: is there a problem”, International Affairs, Vol. 77 No. 1, pp. 31-47.

Murdie, A. (2009), “The impact of human rights NGOs activity on human right practices”, International NGO Journal, Vol. 4 No. 10, pp. 421-440.

Nelson, T.E., Clawson, R.A., and Oxley, Z.M. (1997), "Media Framing of a Civil Liberties Conflict and its Effect on Tolerance”, American Political Science Review, Vol. 91 No. 3, pp. 567-583.

Neumayer, E. (2005),’Do International Human Rights Treaties Improve Respect for Human Rights?”, Journal of Conflict Resolution, Vol. 49 No. 6, pp. 925-953.

Nicholson, S. and Chong, D. (2011), "Jumping on the Human Rights Bandwagon: How Rightsbased Linkages Can Refocus Climate Politics”, Global Environmental Politics, Vol. 11 No. 3, pp. 121-136.

Petrocik, J.R. (1996), "Issue Ownership in Presidential Elections, with a 1980 Case Study”, American Journal of Political Science, Vol. 40 No. 3, pp. 825-850. 
Petty, R.E., Cacioppo, J.T., and Goldman, R. (1981), "Personal Involvement as a Determinant of Argument-Based Persuasion”, Journal of Personality and Social Psychology, Vol. 41 No. 5, pp. 847-855.

Ruggie, J.G. (2007), “Business and Human Rights: The Evolving International Agenda”, The American Journal of International Law, Vol. 101 No. 4, pp. 819-840.

Scheufele, D.A. and Tewksbury, D. (2007), "Framing, Agenda Setting, and Priming: The Evolution of Three Media Effects Models”, Journal of Communication, Vol. 57 No. 1, pp. 9-20.

Sheafer, T. (2007), "How to Evaluate It: The Role of Story-Evaluative Tone in Agenda Setting and Priming”, Journal of Communication, Vol. 57 No.1, pp. 21-39.

Soh, C.S. (1996), “The Korean “Comfort Women”: Movement for Redress”, Asian Survey, Vol. 30 No.12, pp. 1226-1240.

Steinberg, G.M (2011), “The Politics of NGOs, Human Rights and the Arab-Israel Conflict”, Israel Studies, Vol. 16 No 2, pp. 24-54.

Thøgersen, J. (2006), “Media Attention and the Market for 'Green' Consumer Products”, Business Strategy and the Environment, Vol. 15 No. 3, pp. 145-156.

United Nations (1948), The Universal Declaration of Human Rights. Assessed online 26.03.2012 at http://www.un.org/en/documents/udhr/index.shtml

Uscinski, J. (2009), “When Does the Public's Issue Agenda Affect the Media's Issue Agenda (and Vice-Versa)? Developing a Framework for Media-Public Influence”, Social Science Quarterly, Vol. 90 No. 4, pp. 796-815.

Vos, M. and Schoemaker, H. (2006), Monitoring Public Perception of Organisations, Boom Onderwijs, Amsterdam.

Waymer, D. \& Heath, R.L. (2007), "Emergent agents: The forgotten publics in crisis communication and issues management research". Journal of Applied Communication, Vol. 35 No. 1, February 2007, pp. 88-108.

Weiss, D. and Shamir, R. (2011), "Corporate Accountability to Human Rights: The Case of the Gaza Strip”, Harvard Human Rights Journal, Vol. 24 No. 1, pp. 155-183.

Winter, J.P. and Eyal, C. H. (1981), “Agenda Setting for the Civil Rights Issue”, Public Opinion Quarterly, Vol. 45 No. 3, pp. 376-383.

Zhu, J-H. (1992), "Issue Competition and Attention Distraction: A Zero-Sum Theory of AgendaSetting” Journalism Quarterly, Vol. 69 No. 4, pp. 825-836. 